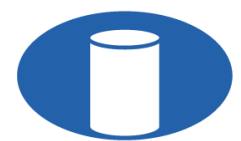

IBRACON Structures and Materials Journal

Revista IBRACON de Estruturas e Materiais

IBRACON

ISSN 1983-4195

ismj.org

ORIGINAL ARTICLE

\title{
Humidity and specimen preparation procedure: influence on compressive strength of concrete blocks
}

\section{Umidade e modo de preparação do corpo de prova: influência na resistência a compressão de blocos de concreto}

\author{
Guilherme Aris Parsekian ${ }^{\mathrm{a}}$ (D) \\ André Luis Christoforo ${ }^{\mathrm{a}}$ (i) \\ Amanda Duarte Escobal Mazzúa ${ }^{\text {iD }}$ \\ Gláucia Maria Dalfré ${ }^{\mathrm{a}}$
}

${ }^{a}$ Universidade Federal de São Carlos - UFSCar, Programa de Pós-graduação em Engenharia Civil, São Carlos, SP, Brasil

Received 01 April 2020

Accepted 10 July 2020

\begin{abstract}
It is extremely important that the quality control of the concrete block used in structural masonry is conducted based on standard procedures that allow reliable estimation of the properties of these components. This work aims to analyze and evaluate the influence of the concrete block moisture on the result of the compression test. Hollow concrete blocks were prepared and subsequently maintained in different environments for various periods of time and under different conditions of temperature and humidity to determine the influence of the type of drying on the relative humidity of the block at the time of testing and consequently on its compressive strength. As a conclusion, it can be stated that, because it is necessary to use water in the process, the grinding rectification of the faces of the blocks led them to have high humidity, above $70 \%$. If tested in this condition, the results of the compressive strength tests will be lower than that of blocks under usual environmental conditions. No differences were found in the average block strength when they were kept dry in the controlled environment of the laboratory during periods of 24 or $48 \mathrm{~h}$. After grinding, it is not necessary to dry the blocks inside an oven at $40^{\circ} \mathrm{C}$ before the tests; simply leaving them at a usual room temperature of $23^{\circ} \mathrm{C}$ and humidity of $40 \pm 5 \%$ for $24 \mathrm{~h}$ is sufficient. The attempt to accelerate drying in an oven at $100^{\circ} \mathrm{C}$ is not adequate because this leads to an increase in the compressive strength. From the results, it was possible to determine expressions to correlate the compressive strength as a function of the moisture of the block at the time of the test. The best-fit expressions are distinct for each block type, but the formulations are consistent in indicating a considerable difference in resistance as a function of moisture.
\end{abstract}

Keywords: moisture, concrete hollow block, compressive strength, statistical analysis, experimental analysis.

Resumo: É de extrema importância que o controle de qualidade de blocos de concreto aplicados na alvenaria estrutural seja realizado com base em procedimentos normalizados que permitam a estimativa das propriedades desses componentes de forma confiável. Este trabalho objetiva analisar e avaliar a influência da umidade do bloco de concreto no resultado do ensaio de compressão. Blocos vazados de concreto simples foram submetidos à processo de retificação e foram posteriormente mantidos em diferentes ambientes, por variados períodos de tempo e sob diferentes condições de temperatura e umidade, de modo a se observar a influência do tipo de secagem sobre a umidade relativa do bloco no momento do ensaio e, consequentemente, sob seu comportamento à compressão. Como conclusão pode-se afirmar que logo após a retificação das face dos blocos, esses apresentam umidade elevada, acima de $70 \%$ e, se ensaiados nessa condição, os resultados de resistência a compressão serão menores que os de blocos em condições ambientais usuais. Não foram verificadas diferenças de resistência para as secagens realizadas nos períodos de 24 ou $48 \mathrm{~h}$ em ambiente laboratorial. Após a retificação não é necessário colocar os blocos em estufa a $40{ }^{\circ} \mathrm{C}$ antes dos ensaios, bastando deixá-los em temperatura e umidade ambiente usuais de $23{ }^{\circ} \mathrm{C}$ e $40 \pm 5 \%$, respectivamente, durante $24 \mathrm{~h}$. A tentativa de acelerar a secagem em estufa a $100{ }^{\circ} \mathrm{C}$ não é adequada pois leva a um aumento da resistência a compressão. A partir dos resultados foi possível determinar expressões para corrigir a resistência

Corresponding author: Guilherme Aris Parsekian. E-mail: parsekian@ufscar.br

Financial support: The São Paulo Research Foundation, FAPESP.

Conflict of interest: Nothing to declare.

This is an Open Access article distributed under the terms of the Creative Commons Attribution License, which permits unrestricted use, distribution, and reproduction in any medium, provided the original work is properly cited. 
a compressão em função da umidade do bloco no momento do ensaio. As expressões de melhor ajuste são distintas para cada tipo de bloco, porém as formulações são consistentes em indicar considerável diferença na resistência em função da umidade.

Palavras-chave: umidade, blocos vazados de concreto, resistência a compressão, análise estatística, análise experimental.

How to cite: G. A. Parsekian, A. L. Christoforo, A. D. E. Mazzú, and G. M. Dalfré, "Humidity and specimen preparation procedure: influence on compressive strength of concrete blocks," Rev. IBRACON Estrut. Mater., vol. 14, no. 2, e14210, 2021, https://doi.org/10.1590/S198341952021000200010

\section{INTRODUCTION}

In Brazil, concrete hollow blocks are one of the most used components in the construction industry due to the simplicity of their production process, which is associated with the ease in obtaining raw materials in Brazil, and the low cost of production, in addition to other advantages provided by the physical characteristics of the blocks.

The great demand for concrete blocks encourages an increase in production and consequently the development of technologies aimed at ensuring the quality of the material. Thus, the regulation and standardization of the quality tests and the specified properties of concrete blocks are important and guarantee the use of specific standards such as the ABNT NBR (Brazilian standard). ABNT specifies various tests to determine the characteristics and properties of concrete blocks, such as water absorption, dimensional tolerance, surface texture, and compressive strength.

The most common control test for hardened concrete is compressive strength testing since it is simple to perform and several of the desirable characteristics of concrete and blocks are qualitatively related to this property, in addition to the importance of knowledge of the concrete compressive strength for structural design [1]. According to Silva [2], the compressive strength test receives greater attention because it is a key factor of masonry resistance in general.

Masonry concrete blocks to be used in structural applications must have a specified compressive strength. Studies have shown that the moisture of blocks at the time of the test directly influences the results of the compressive strength test. Busnello [3] conducted a study to analyze the influence of drying methods and moisture conditions on the results of the compressive strength test of concrete blocks. According to the author, by varying the humidity of the block at the time of the test is it possible to observe differences in its compressive strength of up to $85 \%$. The highest compressive strengths were obtained for blocks with lower humidity.

The NCMA TEK 18-7 [4] indicates that the moisture of the concrete block at the time of the compressive strength test is one of the main variables that needs to be considered, and lower or higher humidity at the time of the test results in increases or decreases of $20 \%$ in the results, respectively.

A study by Butcher [5] indicated increases of up to $10 \%$ in the compressive strength due to the total drying of concrete of $34 \mathrm{MPa}$ and increases of less than $5 \%$ when the drying period is less than $6 \mathrm{~h}$. Shiina [6] identified reductions between 9 and $21 \%$ in the compressive strength of concrete submitted to $48 \mathrm{~h}$ of wetting. According to the concrete inspection manual of the American Concrete Institute [7], differences in compressive strength of up to $25 \%$ can be observed by comparing dry and wet samples of cylindrical concrete specimens.

Permeability is a relevant characteristic that has been mentioned as a source of the variation of compressive strength since it allows a greater amount of water to be in the pores of more permeable concretes [8]. Although there is no universally accepted interpretation of the influence of water on concrete, Galloway et al. [9] stated that the presence of water in concrete pores leads to the dilation of the cement gel, reducing the cohesion of solid particles and consequently its compressive strength. Guo and Waldron [10] presented a mathematical approach to explain the influence of moisture on various physical parameters of concrete, including compressive strength. The model developed by the authors, which was mainly based on the theory of elasticity, demonstrated that compressive strength is the physical factor that is most influenced by moisture, indicating an increase of about $67 \%$ in the tangential tension to the circumference of a cylindrical concrete specimen when its cavities are filled with water.

Busnello's study [3] was mainly responsible for a series of changes in the Brazilian standard NBR 12118 [11] for the execution of compressive strength tests in concrete hollow blocks. One of the main points indicated in this version of the standard is the need to wait for $24 \mathrm{~h}$ for the ground blocks to dry. The justification is that there is a need to use water to perform the grinding rectification of the faces, which increases the humidity of the block and consequently decreases the result of compression resistance. However, some of the changes introduced difficulties in the execution of the tests, such as the increase in the waiting time for drying the block, resulting in a more laborious test procedure in general. The text of this standard specifies moisture ranges to be observed at the time of the test for acceptance of the results, and these ranges vary depending on the resistance of the block. 
For the execution of the compressive strength test of concrete blocks, the block must have its top and bottom faces regularized to ensure the perpendicularity between the faces and the applied load, which allows the uniform transfer of load to the block, and consequently, greater reliability of the results. NBR 12118 [11] recommends that this regularization be performed by either applying pastes or mortars capable of resisting the expected stresses or through grinding, which consists of the wear of a thin layer of the face of the block. According to Bezerra [12], rectification must be performed in such a way so as to preserve the structural integrity of the layers below the removed thin layer, resulting in a surface without ripples, bulging, and without breakings at the edges of the concrete block.

The grinding process has the advantage of reduced execution time compared to the time associated with the preparation of pastes and mortars and of a less laborious execution process. However, as mentioned earlier, during the grinding process, the blocks are inevitably moistened by the water, a fact that should be considered at the time of the compressive strength test.

The fact that moisture helps in the process of curing and development of concrete compressive strength is already widely known. According to Popovics [13], the moisture condition to which concrete specimens are submitted in the days prior to the compressive strength test affects the results obtained. However, with different compositions, concrete specimens submitted to air drying in the days prior to the compressive strength test showed higher resistance. According to the author, in a concrete specimen that is externally subjected to wetting (happens during the grinding process in which the wetting is superficial, generating a moisture gradient), the surface tries to expand creating biaxial tensile stresses in the core of the specimen, which opposes this expansion. Thus, stresses are generated in the third direction of the specimen, thus leading to the reduction of its compressive strength. In the case of concrete blocks, elements that have relatively thin walls, with internal and external surfaces, there is the possibility that the stresses generated by external wetting are even higher.

The American standard ASTM C140/C140M [14] recommends that concrete blocks be subjected to air drying at a temperature of $24 \pm 8^{\circ} \mathrm{C}$ and not dried in an oven since drying in an oven can lead to a state of stresses that can alter the test result, causing increased resistance to apparent compression. This standard, similar to the Australian/New Zealand standard AS/NZS 4456 [15], further recommends that the humidity condition of the block at the time of the test should be close to the condition observed when the block was received, thus ensuring that the actual capacity of the block is determined. The British standard BS EM 772-1 [16] presents a detailed method for determining the allowed block moisture condition before the compressive strength test, considering the type of material that composes the block and the type of capping (regularization of the work faces of the block) that is used.

The most current version of the ABNT NBR 12118 [11] describes, separately, the treatments to which blocks capped with pastes and mortars and rectified blocks should be submitted. In the case of rectified blocks, periods and temperature ranges are included for drying in an oven and air drying. In the case of air drying, the standard recommends that the blocks be placed in a laboratory environment for $72 \mathrm{~h}$. On the other hand, for drying in an oven, these should be kept in an oven for $24 \mathrm{~h} \pm 30 \mathrm{~min}$, with a temperature of $40 \pm 2{ }^{\circ} \mathrm{C}$.

In contrast to the Brazilian standard, the British and American standards establish that concrete blocks must be tested in the wet condition, a condition that, according to Neville [1], is more easily reproduced since dry conditions include several degrees of drying.

Thus, it is necessary to standardize the treatment of masonry concrete blocks for the humidity condition to reduce the influence of this factor on the test.

The existence of only a few studies for the specific case of concrete hollow blocks justifies the need to seek more information regarding the influence of moisture of these blocks on their compressive strength, considering that this can be directly related to the safety assurance and quality control of the material.

Thus, this work aims to determine the influence of the moisture of masonry concrete blocks on their compressive strength, submitting rectified concrete blocks to drying in different environments, for various periods of time and under different conditions of temperature and humidity, besides analyzing whether the wetting caused by the grinding process is relevant.

\section{MATERIALS AND METHODS}

To evaluate the influence of moisture of masonry concrete blocks on their compressive strength, rectified concrete blocks with different moisture levels were submitted to tests to determine their compressive strength. The drying methods used to obtain the different moisture levels for the rectified blocks are presented in Table 1. 
Table 1. Drying method and moisture condition of the blocks.

\begin{tabular}{cccc}
\hline Condition & Drying/saturation method & Temperature/Humidity & Duration (hours) \\
\hline 1 & Air-conditioned room & $23^{\circ} \mathrm{C} / 40 \pm 5 \%$ & 24 \\
\hline 2 & Air-conditioned room & $23^{\circ} \mathrm{C} / 40 \pm 5 \%$ & 48 \\
\hline 3 & Oven & $100 \pm 5{ }^{\circ} \mathrm{C}$ & 24 \\
\hline 4 & Oven & $40 \pm 5{ }^{\circ} \mathrm{C}$ & 24 \\
\hline 5 & Saturated in water & Environment & 24 \\
\hline 6 & No* & Environment & - \\
\hline
\end{tabular}

* concrete blocks tested right after rectification. Source: Tchalekian [17]

Three different types of concrete blocks with dimensions of $14 \times 19 \times 29 \mathrm{~cm}$ (group A), $19 \times 19 \times 39 \mathrm{~cm}$ (group B), and $14 \times 19 \times 39 \mathrm{~cm}$ (group C) with specified compressive strengths of 12, 8, and $22 \mathrm{MPa}$, respectively, were analyzed. Each group was composed of six concrete blocks for each moisture condition, totaling 36 blocks for each group, totaling 108 blocks analyzed. Three blocks, for each moisture condition, from each group, were used to determine the relative humidity of the blocks by measuring their dry and saturated masses. The blocks used for the determination of the relative humidity were not submitted to the compressive strength test. The blocks used in the relative humidity test were submitted to the same processes and environmental conditions as those used for compressive strength tests until the moment of the test. At that moment, the humidity control blocks were taken to the oven. Thus, their conditions mirrored the moisture of the blocks tested in compression.

\subsection{Preparation of concrete blocks}

Prior to exposure to the environments presented in Table 1, the dimensions of the blocks were measured with the aid of a caliper, thus allowing the calculation of the gross area, with the resistance calculated in relation to this area.

All blocks were submitted to wet rectification, which was performed on the top and bottom faces of the blocks. Before the fixation of the blocks in the grinding support, all particles that could interfere in the leveling of the samples were removed with the help of a brush. The process of rectification and the measurement of the dimensions of the blocks are exemplified in Figure 1.

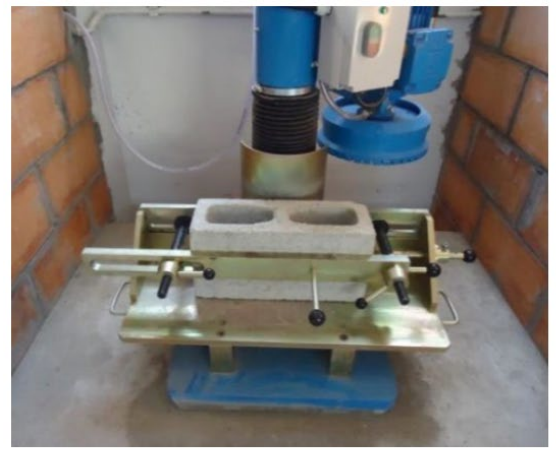

(a)

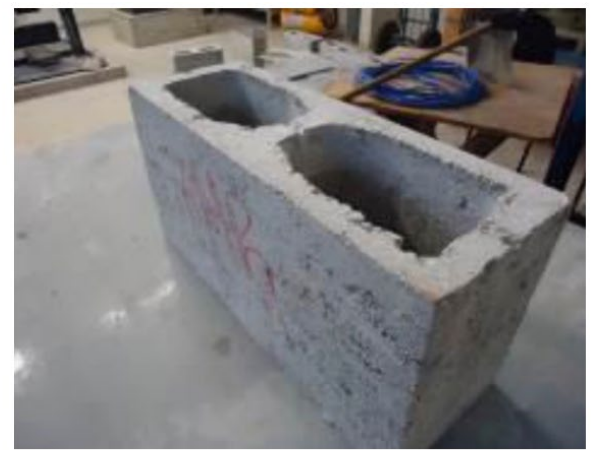

(b)

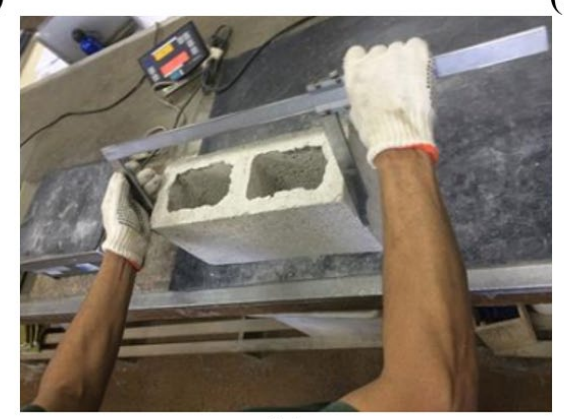

(c)

Figure 1. (a) grinding process, (b) rectified block and (c) dimension measurement. Source: Tchalekian [17] 
After rectification, the blocks were placed in the environments detailed in Table 1, and in the case of drying in an oven (shown in Figure 2a), the blocks were positioned in such a way so as to facilitate the circulation of air between the samples. The blocks to be saturated were placed into a water tank and fully submerged, as shown in Figure $2 b$.

The method described in NBR 12118 [11] was used to determine the relative humidity of the blocks. For this, the dry mass, wet mass, and mass at the time of the test were determined, and the relative humidity was calculated using Equation 1.

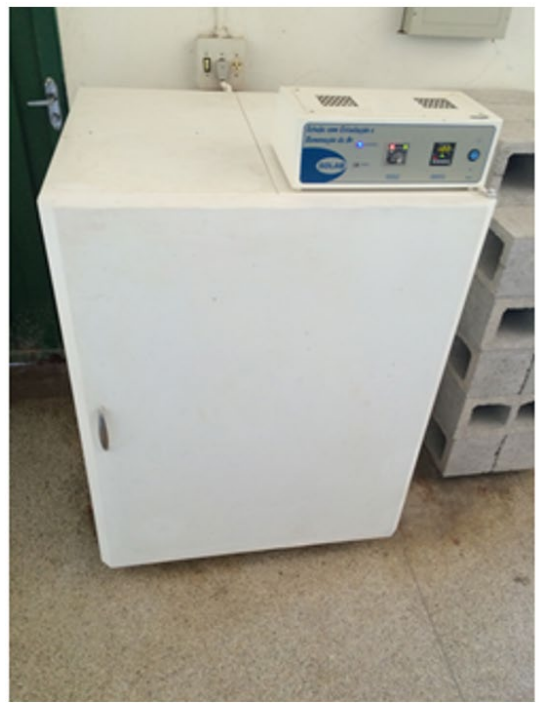

(a)

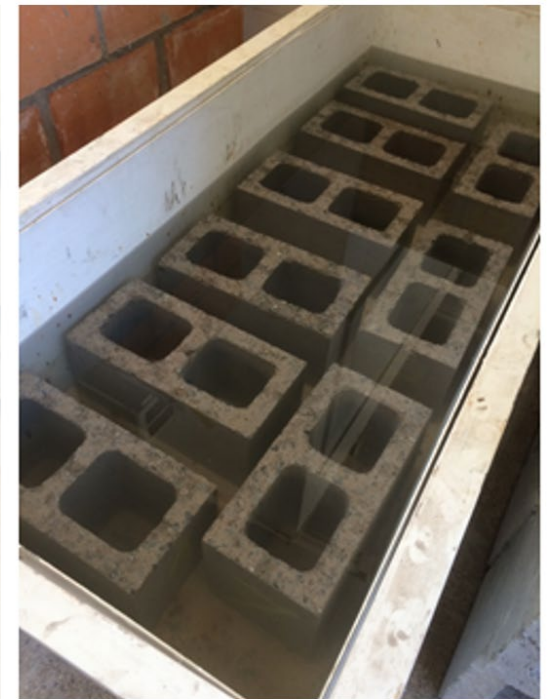

(b)

Figure 2. Exhibition environments - Oven (a) and Water tank (b). Source: Tchalekian [17]

$\mathrm{U}=\left(\frac{\mathrm{m}-\mathrm{m}_{1}}{\mathrm{~m}_{2}-\mathrm{m}_{1}}\right) \cdot 100$

where $\mathrm{U}$ is the relative moisture content of the block in percentage, $\mathrm{m}$ is the mass of the block at the time of the test in grams, $\mathrm{m}_{1}$ is the mass of the dry block in grams in an oven at $(110 \pm 5)^{\circ} \mathrm{C}$, and $\mathrm{m}_{2}$ is the mass of the saturated block in grams.

The compressive strength tests were performed at the Structural Systems Laboratory (LSE) of the Federal University of São Carlos (UFSCar) using an EMIC universal testing machine, model PC200-ESP, which was configured to applied the load at the speed required in the standard. A data acquisition system, LYNX model ADS-2000, was used to record the load. During the tests, the specimens were positioned with their center of gravity aligned with the load axis of the test machine platens and with the thicker side of the webs at the top, which is the position that blocks are employed.

By applying the method recommended by NBR 6136 [18], it was possible to estimate the value of compressive strength $\left(\mathrm{f}_{\mathrm{bk}, \text { est }}\right)$ for each group using Equation 2.

$\mathrm{f}_{\mathrm{bk}, \text { est }}=2 \cdot\left(\frac{\mathrm{f}_{\mathrm{b}(1)}+\mathrm{f}_{\mathrm{b}(2)}+\ldots \mathrm{f}_{\mathrm{b}(\mathrm{i}-1)}}{\mathrm{i}-1}\right)-\mathrm{f}_{\mathrm{b}(\mathrm{i})}$

where $f_{b k, e s t}$ is the estimated characteristic resistance of the sample $(\mathrm{MPa}) ; \mathrm{f}_{\mathrm{b}(1)}, \mathrm{f}_{\mathrm{b}(2)}, \ldots$, are the individual compressive strength values of the specimens, ordered increasingly, $n$ is the number of blocks; and $i=n / 2$ if $n$ is even or $\mathrm{i}=(\mathrm{n}-1) / 2$ if $\mathrm{n}$ is odd. $\mathrm{f}_{\mathrm{bk} \text {,est }}$ should not be taken as less than $\psi \cdot \mathrm{f}_{\mathrm{b}(1)}$, where $\psi$ accounts for the number of blocks and is given in Table 1 of ABNT NBR 6136 [18]. 


\subsection{Statistical treatment}

For each type of concrete hollow block (A, B and C) and moisture condition presented in Table 1, one experimental treatment (Tr) was designed, totaling six different experimental treatments (Tr), and, for each treatment, six blocks were tested.

The Tukey multiple comparison test, at the $5 \%$ level of significance, was used to identify possible significant differences between the values of compressive strength $\left(\mathrm{f}_{\mathrm{b}}\right)$ for the six treatments (per block type). In the Tukey test, "A" denotes the treatment of higher mean value, "B" the second highest mean value, and so on, and equal letters imply treatments with statistically equivalent means.

Significant differences reported by the Tukey test between treatments $\operatorname{Tr} 1$ and $\operatorname{Tr} 2$ show that the drying period (24 or $48 \mathrm{~h}$ ) of the samples evaluated in an air-conditioned room were considered significant for the compressive strength values. If a significant difference between treatments 3 and 4 is assumed, it implies that the temperature of the oven ( 40 or $100^{\circ} \mathrm{C}$ ) affects the values of $\mathrm{f}_{\mathrm{b}}$. If there is a significant difference between treatments $1,2,3,4$ and treatment 5 , it implies that there is no difference in the resistance values between the dry blocks in the air-conditioned room or that of blocks saturated in water at room temperature and kept in an oven; the same for treatment 6 (unsaturated and dry at room temperature).

In order to establish a unique relationship between compressive strength $\left(f_{b}\right)$ and relative moisture content $(U)$ for the three types of blocks (A, B, and C), the mean values of $\mathrm{f}_{\mathrm{b}}$ for the respective moisture content $\left(\mathrm{f}_{\mathrm{b}, \mathrm{U}(\%)}\right)$ for each block type were normalized by the mean values of $\mathrm{f}_{\mathrm{b}}$ for the condition of $0 \%$ humidity $\left(\mathrm{f}_{\mathrm{b} .0 \%}\right)$. The consideration of block $\mathrm{B}$ along with blocks $\mathrm{A}$ and $\mathrm{C}$ impaired the accuracy of the regression models. Due to this, different best-fit models are generated (Equations 3 and 4), the first one for the set involving blocks $\mathrm{A}$ and $\mathrm{C}$ and a second model exclusively for block B. The regression models presented in Equations 3 and 4, based on ANOVA (at the level of 95\% reliability) at two parameters ( $\alpha$ o and $\alpha_{1}$ ) were created. Considered significant by ANOVA, the best fit by block type was defined based on the coefficient of determination value $\left(\mathrm{R}^{2}\right)$.

$\mathrm{f}_{\mathrm{b}, \mathrm{U}(\%)} / \mathrm{f}_{\mathrm{b}, 0 \%}=\alpha_{0}+\alpha_{1} \cdot \mathrm{U}+\varepsilon[$ linear $]$

$\mathrm{f}_{\mathrm{b}, \mathrm{U}(\%)} / \mathrm{f}_{\mathrm{b}, 0 \%}=\alpha_{0} \cdot \mathrm{U}^{\alpha_{1}}+\varepsilon[$ geometric $]$

Based on the formulation of the ANOVA of the regression models of Equations 3 and 4, a p-value lower than the significance level implies that the models are significant, and not significant otherwise (i.e., for $p$-value $\geq 0.05$ ). The Anderson-Darling test ( $5 \%$ significance) was used to verify normality ( $p$-value $\geq 0.05)$ in the distribution of the residues, to validate the ANOVA model.

\section{RESULTS AND DISCUSSION}

\subsection{Compressive strength and relative humidity tests}

The average results obtained for the blocks of group A are presented in Table 2 while the average results obtained for the blocks of groups B and C are presented in Tables 3 and 4, respectively.

Table 2. Results obtained for group A blocks.

\begin{tabular}{cccccc}
\hline Condition & Number of blocks & $\begin{array}{c}\text { Relative } \\
\text { Humidity of } \\
\text { the Block (\%) }\end{array}$ & $\mathbf{f}_{\mathbf{b m}}$ (MPa) & $\mathbf{f}_{\mathbf{b k}}(\mathbf{M P a})$ & Coefficient of Variation (\%) \\
\hline 1 & 6 & $31 \%$ & 14.08 & 12.60 & 8.03 \\
\hline 2 & 6 & $31 \%$ & 15.61 & 13.84 & 6.90 \\
\hline 3 & 6 & $0 \%$ & 19.83 & 19.02 & 2.36 \\
\hline 4 & 6 & $32 \%$ & 16.25 & 14.44 & 6.31 \\
\hline 5 & 6 & $100 \%$ & 12.94 & 10.61 & 7.27 \\
\hline
\end{tabular}

Source: Tchalekian [17] 
Table 3. Results obtained for group B blocks.

\begin{tabular}{cccccc}
\hline Condition & Number of blocks & $\begin{array}{c}\text { Relative } \\
\text { Humidity of } \\
\text { the Block (\%) }\end{array}$ & $\mathbf{f}_{\text {bm }}$ (MPa) & f fbk (MPa) & Coefficient of Variation (\%) \\
\hline 1 & 6 & $30 \%$ & 9.87 & 9.30 & 2.13 \\
\hline 2 & 6 & $27 \%$ & 10.47 & 9.47 & 5.02 \\
\hline 3 & 6 & $0 \%$ & 12.70 & 12.13 & 2.24 \\
\hline 4 & 6 & $32 \%$ & 14.38 & 12.92 & 4.86 \\
\hline 5 & 6 & $100 \%$ & 12.13 & 9.66 & 6.86 \\
\hline 6 & 6 & $72 \%$ & 12.35 & 8.02 & 15.57 \\
\hline
\end{tabular}

Source: Tchalekian [17]

Table 4. Results obtained for group C blocks.

\begin{tabular}{cccccc}
\hline Condition & Number of blocks & $\begin{array}{c}\text { Relative } \\
\text { Humidity of } \\
\text { the Block (\%) }\end{array}$ & $\mathbf{f}_{\text {bm }}$ (MPa) & f fbk (MPa) & Coefficient of Variation (\%) \\
\hline 1 & 6 & $50 \%$ & 12.57 & 10.51 & 11.23 \\
\hline 2 & 6 & $49 \%$ & 12.39 & 10.95 & 7.18 \\
\hline 3 & 6 & $0 \%$ & 14.91 & 12.27 & 10.33 \\
\hline 4 & 6 & $38 \%$ & 12.44 & 9.50 & 14.59 \\
\hline 5 & 6 & $100 \%$ & 11.74 & 7.89 & 15.00 \\
\hline 6 & 6 & $86 \%$ & 10.28 & 7.97 & 14.17 \\
\hline
\end{tabular}

Source: Tchalekian [17]

\subsection{Statistical treatment}

The mean values, the mean confidence intervals (at the 95\% reliability level), and the Tukey test results of the compressive strength values as a function of the experimental mental treatments for each block type are summarized in Figure 3.

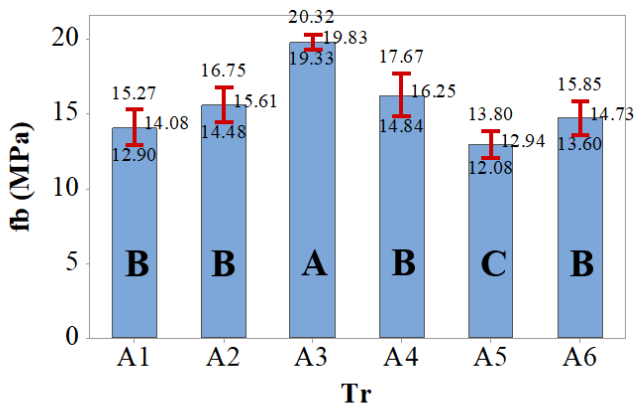

(a)

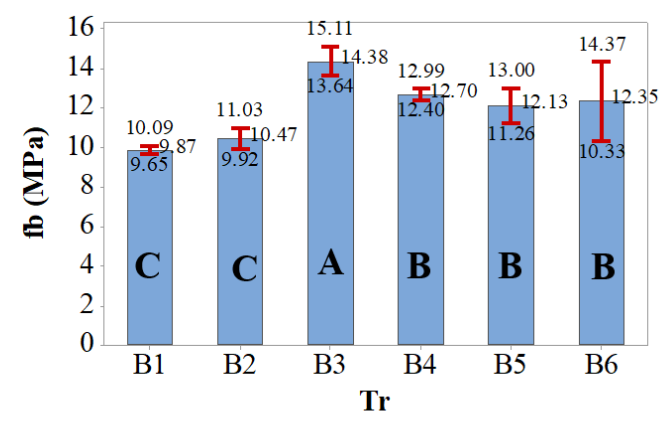

(b)

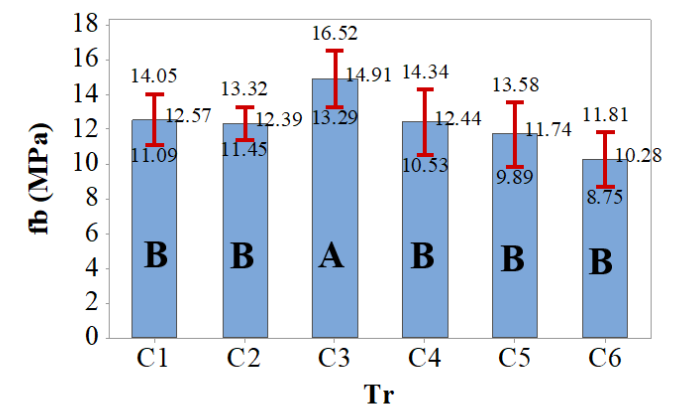

(c)

Figure 3. Results of compressive strength $\left(f_{b}-M P a\right)$ for the six experimental treatments. 
As shown in Figure 3a, the highest value $\mathrm{f}_{\mathrm{b}}$ was for treatment A3, which consisted of the use of the oven at $100^{\circ} \mathrm{C}$ for $24 \mathrm{~h}$. The second highest mean value $\mathrm{f}_{\mathrm{b}}$ was observed for treatments A1, A2, A4, and A6. This implies that the exposure time of 24 or $48 \mathrm{~h}$ of samples in an air-conditioned room did not significantly affect the compressive strength values. An increase of approximately $22 \%$ in $\mathrm{f}_{\mathrm{b}}$ was observed when the temperature of the oven increases from $40^{\circ} \mathrm{C}$ to $100^{\circ} \mathrm{C}$, and it should be noted that treatments A1, A2, and A4 were equivalent to treatments A6, which consisted of drying the block in the environment. Thus, for blocks with dimensions of $14 \times 19 \times 29 \mathrm{~cm}$, the air-drying period of $72 \mathrm{~h}$ recommended by ABNT NBR 12118 [11] for blocks kept in a laboratory environment (air-conditioned room) or dried in an oven with a temperature of $40^{\circ} \mathrm{C}$ for $24 \mathrm{~h}$, the results obtained were statistically equivalent to the results obtained without the samples undergoing any type of drying. As mentioned in the American standard, drying in an oven at $100^{\circ} \mathrm{C}$ for $24 \mathrm{~h}$ increased the compressive strength values, probably due to the presence of a previous state of tensions.

For blocks of dimensions $19 \times 19 \times 39 \mathrm{~cm}$, as shown in Figure $3 \mathrm{~b}$, the highest value $\mathrm{f}_{\mathrm{b}}$ was obtained for treatment $\mathrm{B} 3$, which consisted of the use of an oven at $100^{\circ} \mathrm{C}$ for $24 \mathrm{~h}$. The second highest mean value is to treatments B4, B5, and B6, which were considered statistically equivalent; treatments B1 and B2 resulted in the lowest mean values of compressive strength. Furthermore, as it occurred with blocks of dimensions $14 \times 19 \times 29 \mathrm{~cm}$, the drying time of 24 or $48 \mathrm{~h}$ in an air-conditioned room neither significantly affect the values of compressive strength. The temperature of $100^{\circ} \mathrm{C}$ increased approximately) the compressive strength between treatments B5 and B6.

As shown in Figure 3c, and as observed for the two other types of block, treatment $\mathrm{C} 3$ resulted in the highest mean value of $f_{b}$, the other treatments are equivalent to each other and significantly lower than treatment $\mathrm{C} 3$. This implies that the drying time of 24 or $48 \mathrm{~h}$ in an air-conditioned room did not significantly affect the values of the compressive strength nor did the temperature of $40^{\circ} \mathrm{C}$ or $100^{\circ} \mathrm{C}$ in the oven significantly affect the values of compressive strength. These results are equivalent to the conditions of saturating in water for $24 \mathrm{~h}$ or drying in the environment.

The mean values and confidence intervals of the mean (at the $95 \%$ reliability level) relative humidity $\left(\mathrm{U}_{\mathrm{r}}\right)$ for the six experimental treatments per block type are presented in Figure 4.

For all types of block, the relative humidity obtained by air drying in a laboratory environment (air-conditioned room) for $24 \mathrm{~h}$ or $48 \mathrm{~h}$ and the relative humidity obtained by drying in an oven at $40^{\circ} \mathrm{C}$ for $24 \mathrm{~h}$ were similar. The drying condition in an oven at $100^{\circ} \mathrm{C}$ for $24 \mathrm{~h}$ led to the total drying of all types of block used, implying much higher results in $\mathrm{f}_{\mathrm{b}}$ in all cases.

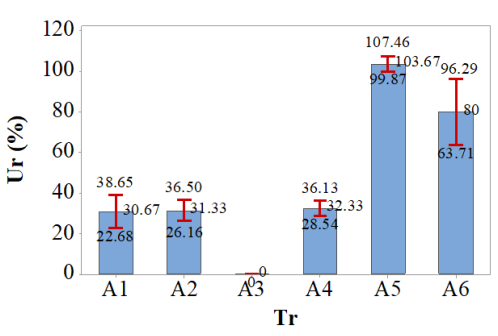

(a)

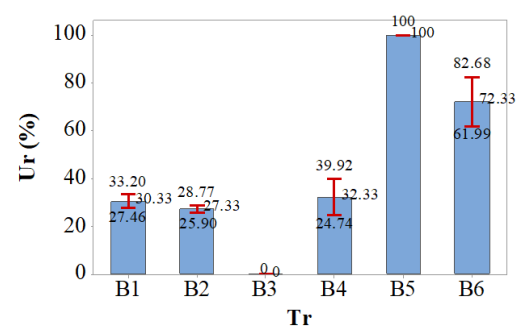

(b)

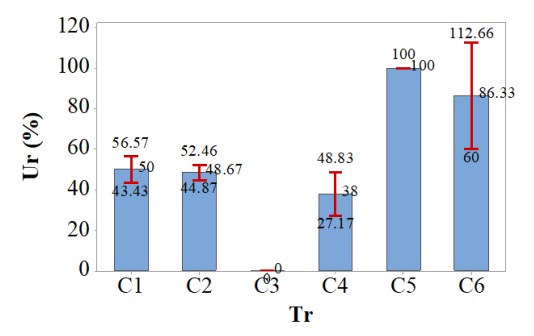

(c)

Figure 4. Relative humidity results ( $\left.U_{r}-\%\right)$ referring to the six experimental treatments per block type $-14 \times 19 \times 29 \mathrm{~cm}(\mathrm{a})$, $19 \times 19 \times 39 \mathrm{~cm}(\mathrm{~b})$ and $14 \times 19 \times 39 \mathrm{~cm}(\mathrm{c})$. 
The results obtained with the use of the regression models (best adjustments based on equations 3 and 4 ) for the set of blocks of $14 \mathrm{~cm}$ (blocks A and C) and $19 \mathrm{~cm}$ (block B) are presented in Figure 5.

For blocks A $\left(14 \times 19 \times 29 \mathrm{~cm} ; \mathrm{f}_{\mathrm{bk}}=12 \mathrm{MPa}\right)$ and $\mathrm{C}\left(14 \times 19 \times 39 \mathrm{~cm} ; \mathrm{f}_{\mathrm{bk}}=22 \mathrm{MPa}\right)$, as shown in Tables 2 and 4, the highest values of the mean resistance $\mathrm{f}_{\mathrm{b}}$ are associated with the lowest relative humidity content $(0 \%)$, and as the relative humidity progressively increases, the compressive strength experiences successive reductions as expected; however, for block $\mathrm{B}\left(19 \times 19 \times 39 \mathrm{~cm} ; \mathrm{f}_{\mathrm{bk}}=8 \mathrm{MPa}\right)$, the resistances $\mathrm{f}_{\mathrm{b}}$ at $0 \%$ and $100 \%$ relative humidity were practically equivalent.

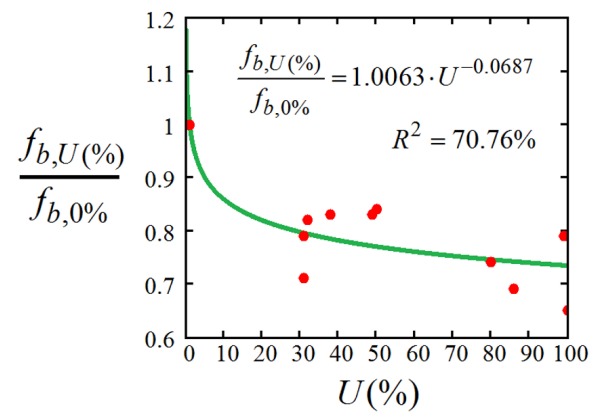

(a)

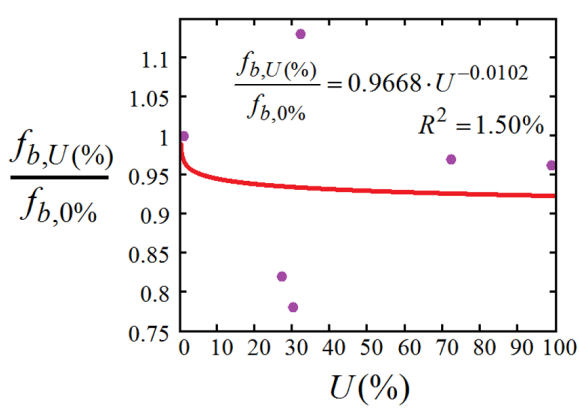

(b)

Figure 5. Ratio values between wet and dry compressive strength as a function of relative moisture content considering the grouping of the results of blocks A and C (a) and blocks B (b) alone.

As shown in Figure 5a, the model considering the set of results between $\mathrm{f}_{\mathrm{b}, \mathrm{U}(\%)} / \mathrm{f}_{\mathrm{b} .0 \%}$ and the relative humidity (U) of blocks $A$ and $C$ provided a coefficient of determination $\left(\mathrm{R}^{2}\right)$ approximately equal to $71 \%$, which is considered significant by ANOVA (5\% significance). In contrast, the model for block B is non-significant by the analysis of variance and small precision; $\mathrm{R}^{2}$ value of less than $2 \%$ as shown in Figure $5 \mathrm{~b}$. For both the models the $\mathrm{p}$-values of the normality test were higher than 0.05 , which verified the validity of these models. However, the geometric (Equation 4 ) was observed to best adhere to the results. Only as a reference, for blocks A or C, the increase in humidity from $30 \%$ to $100 \%$ promotes a reduction of $6.41 \%$ for $\mathrm{f}_{\mathrm{b}, \mathrm{U}(\%)} / \mathrm{f}_{\mathrm{b} .0 \%}$.

\section{CONCLUSIONS}

This work aimed to analyze the influence of the relative humidity of masonry concrete blocks on their compressive strength. For this, sets of blocks with dimensions of $14 \times 19 \times 29 \mathrm{~cm}, 19 \times 19 \times 39 \mathrm{~cm}$, and $14 \times 19 \times 39 \mathrm{~cm}$ were rectified, submitted to different humidity conditions for different periods of time and under different temperature conditions, and subsequently submitted to compressive strength test.

The conclusions of this research are the following:

- The relative humidity condition of the block influences the compressive strength of masonry concrete blocks;

- Drying concrete blocks in the oven for $24 \mathrm{~h}$ at a temperature of $100^{\circ} \mathrm{C}$ considerably increases their compressive strength;

- Drying blocks in an oven for $24 \mathrm{~h}$ at $40^{\circ} \mathrm{C}$ results in compressive strengths similar to those of drying the blocks at a temperature of $23^{\circ} \mathrm{C}$;

- When blocks are dried at a temperature of $23^{\circ} \mathrm{C}$, drying times of $24 \mathrm{~h}$ and $48 \mathrm{~h}$ results in similar compressive strengths;

- Blocks tested immediately after the grinding procedure have relative humidity in the range of $72-86 \%$ and compressive strengths similar to those of blocks that are saturated to $100 \%$ humidity before the test, with both cases resulting in lower resistance values than that from other humidity situations. Therefore, testing saturated or ground blocks soon after the grinding procedure will lead to lower compressive strengths.

There is no difference between waiting 24 or $48 \mathrm{~h}$ for the blocks to dry; it is not necessary to put them in an oven at $40^{\circ} \mathrm{C}$; just leave them in the ambient temperature and humidity of $23^{\circ} \mathrm{C}$ and $40 \pm 5 \%$, respectively. Trying to accelerate the drying at $100^{\circ} \mathrm{C}$ is not suitable, as it leads to increased compressive strength. 
Expressions to correct the compressive strength as a function of the moisture for $14 \mathrm{~cm}$ and $19 \mathrm{~cm}$ blocks at the time of test were developed. For $14 \mathrm{~cm}$ blocks, the increase of humidity from $30 \%$ to $100 \%$ promotes a reduction of $6.41 \%$ for $\mathrm{f}_{\mathrm{b}, \mathrm{U}(\%)} / \mathrm{f}_{\mathrm{b} .0 \% \ldots}$

For the $19 \mathrm{~cm}$ blocks, the moisture has a smaller influence on the compressive strength of the block. The reason for this behavior needs to be further studied.

\section{ACKNOWLEDGEMENTS}

The authors would like to thank the Laboratory of Structural Systems of UFSCar for their support in conducting the tests, the Foundation for Research Support of the State of São Paulo (FAPESP), process no. 2016/10460-7, and the undergraduate student Daniel Borsero Tchakelian for conducting the tests. This work was carried out with the support of the Coordination for the Improvement of Higher Education Personnel—Brazil (CAPES)—Financing Code 001. The authors would also like to thank Glasser Pisos e Pré-Moldados for donating the blocks.

\section{REFERENCES}

[1] A. M. Neville, Propriedades do Concreto, 5th ed. Porto Alegre: Bookman, 2016, pp. 626-627.

[2] A. F. Silva, “Avaliação da resistência à compressão da alvenaria estrutural,” M.S. thesis, Fac. Eng. Ilha Solteira, Univ. Est. Paul., 2007. [Online]. Available: http:/hdl.handle.net/11449/91473

[3] E. C. Busnello, "Aprimoramento tecnológico e contribuições na execução de ensaios de bloco de concreto para redução da dispersão de resultados," in Sem. Alv. Estrut. Blocos de Concr. Concrete Show, São Paulo, 2011. [Online]. Available: http:/www.blocobrasil.com.br/downloads/file/25-nbr-12-118-2011-aprimoramento-tecnologico-e-contribuicoes-na-execucao-de-ensaios-debloco-de-concreto-para-reducao-da-dispersao-de-resultados-emerson-cremm-busnello

[4] National Concrete Masonry Association, Compressive Strength Testing Variables for Concrete Masonry Units, NCMA TEK 18-7. Herndon: NCMA, 2004.

[5] W. S. Butcher, "The effect of air drying before test: 28-day strength of concrete," Constructional Rev., pp. 31-32, 1958.

[6] K. Shiina, Influence of temporary wetting at the time of test on compressive strength and Young's modulus of air-dry concrete," in Proc. 36th Gen. Meet., 1982, pp. 113-115.

[7] American Concrete Institute, ACI Manual of Concrete Inspection, 4th ed. Detroit: ACI, 1957.

[8] American Concrete Institute, Guide for Obtaining Cores and Interpreting Compressive Strength Results, ACI Committee 214.4R, 2003.

[9] J. W. Galloway, H. M. Harding, and K. D. Raithby, "Effect of moisture changes of flexural and fatigue strength of concrete," Transp. Road Res. Lab., no. 864, 1979.

[10] J. S. Guo and P. Waldron, "An elastic model to quantify the effect of moisture on the mechanical properties of concrete at the time of test," Mag. Concr. Res., vol. 53, no. 3, pp. 151-162, 2001.

[11] Associação Brasileira de Normas Técnicas, Blocos Vazados de Concreto Simples para Alvenaria - Métodos de Ensaio - Versão Corrigida, NBR 12118:2013, 2014.

[12] A. C. S. Bezerra, "Influência das variáveis de ensaio nos resultados de resistência à compressão de concretos: Uma análise experimental e computacional,” M.S. thesis, Univ. Fed. Minas Gerais, 2007. [Online]. Available: http:/hdl.handle.net/1843/ISMS-74UPHH

[13] S. Popovics, "Effect of curing method and final moisture condition on compressive strength of concrete," ACI J., vol. 83, no. 4, pp. 650-657, 1986.

[14] American Society for Testing and Materials, Standard Test Methods for Sampling and Testing Concrete Masonry Units and Related Units Designation, C140/C140M-16, 2016.

[15] Australian/New Zealand Standard, Masonry Units, Segmental Pavers and Flags - Methods of Test, AS/NZS 4456.4:2003, 2003.

[16] BSI Standards, Methods of Test for Masonry Units, BS EN 772-1:2011+A1:2015, 2015.

[17] D. B. Tchalekian, Avaliação da Influência da Umidade na Resistência à Compressão de Blocos Vazados de Concreto - Relatório Final de Iniciação Científica. São Carlos: Universidade Federal de São Carlos, 2016.

[18] Associação Brasileira de Normas Técnicas, Blocos Vazados de Concreto Simples para Alvenaria - Requisitos - Versão Corrigida, NBR 6136:2016, 2016.

Author contributions: G. A. Parsekian: supervision, experimental methodology, experimental analysis, writing; A. L. Christoforo: statistical methodology, statistical analysis, writing; A. D. E. Mazzú: conceptualization, writing, formatting; G. M. Dalfré: writing.

Editors: Fernando S. Fonseca, José Luiz Antunes de Oliveira e Sousa. 